\title{
THE PHILOSOPHICAL NEED OF PEACE EDUCATION
}

\author{
Ferit Baça \\ University of Tirana, Albania
}

\begin{abstract}
The concept of peace includes the phenomenon of the lack of conflict and the existence of a healthy climate of human relations, inside and outside the country. So, we could also include the existence of harmony in social relations, economical welfare, the climate of equality, and justice in political relations or said in a more concentrated way, the picture of a state without war and conflicts. But another definition for peace includes even keeping the balance in human relations, tolerance, and the way of resolving problems through dialog and deals between the two conflicted groups. Peace is a typical and a dominating element in a democratic society, because it is built on the strong foundations of respect for the universal law of freedom and human rights. However, the concept of peace, has not escaped from the different interpretations varying on the circumstances and conditions of the existence of a population, culture and cultural level it inherits, also historical and political context of the time. The study analyzes some of the philosophical concepts on peace, its evolution in the flow of history and the need of it in our modern era. Thus, for accomplishing this research, I referred to different books dealing with relevant subjects such as peace and conflict, by using the method of analyzing and interpreting.
\end{abstract}

Keyword: democratic society, conflicted groups, human relations, peace education.

\section{Introduction}

Being in essence the incarnation of life itself, to phenomenon of peace, there was always reserved a permanent treatment, from philosophers of all times. So, it was incarnated in the concept of a divine right, as an entirety of rights, that we were born with, and based in the existence and nature of every person. Consequently, there is no other thing, nonnegotiable for every human being and human society as freedom. The argument is simple and clear as the light of sun, every man has equal natural rights, despite gender and age, position in society, time, place and the social order he lives in. Natural rights are primary inalienable rights, "permanent", in distinction with laws and juridical norms that respond to level and social order. We find the roots of the idea of natural rights in the works of the Greek philosophers of antiquity, Plato and Aristotle.

While regarding the religious literature, I find the first concepts on peace in Old Testament and Qur'an, where peace is defined as a match of relation between God and man. The demands for peace were closely related to the realization of necessary requests for the continuity of life like health, satiation and welfare. Moreover, In the Christian philosophy, especially in that of Thomas Aquinas (1225-74) and scholars, the natural rights were considered as a work of God that leads the life of man. The origin of the concept and the meaning of peace has its roots in antiquity. The term "peace" has its origin from the ancient English that means "freedom from conflicts" and from the Latin language "pax". 
In the period of antiquity peace symbolizes harmony, tolerance and understanding. In our days this concept refers not only to the achievement of peace through individuals of society, but it also incarnates a meditative and reflecting context, such as "being in peace with yourself", that means reaching a state of silence and harmony with yourself. So as far as we see, we can say that the origin of this concept has evolved with time and has known a wider meaning. The realization of needs and requirements for a better and peaceful life, pointed out the need of fighting over arbitrary attitudes, oppression and exploitation from monarchs.

In the ancient historical documents, there are counted a number of important duties towards kings for the security of citizens, besides the fights with the opponents of the monarch, making sure that they have the most important vital things, without forgetting the establishment of a relative righteousness according to the circumstances of time. In a democratic society, the concept of natural rights is concretized with the basic human and civil rights, over which the state of the right is based in today's world. However, the main purpose of the research is to understand the need of peace education and its application in today's societies.

\section{The Philosophical Concepts about Peace}

In the beginning of the middle Ages, in the period of formation of territorial states and absolutism, the concepts of peace and justice didn't play any important role, but they were obvious after Enlightenment and French revolution emerged. Naturally the norm of disclosure of existence is attributed to the concepts of welfare and democracy. Even after the above proposals, having a deep philosophical and political streak, Kant didn't offer any guarantee that his confederation will not be dissolved and could not fall from the beginning from military powers. But it is important, concerning the idea of Kant, that every guarantee that can be given for the success of his confederation, has to be connected, in every stage of development with the continuous remembrance of possibility, risk and threaten, so that its members can choose as a tool to achieve their goals, the bloody and irresponsible war. (Kant. 2004, P. 113).

Kant had totally understood that the task of approaching different nations of mankind in order to take the same initiatives, to do the same thing, and to maintain those initiatives, would be long and tiring, would be from the last ones that would be resolved from human kind and, when it would seem it had been resolved once for all, it would remain a field with a lot of potential for misunderstanding and tendencies to return back to violent solutions. According to Spinoza, peace is not lack of war. Peace is a virtue, an intellectual attitude, a tendency towards good, faith and justice (Spinoza 2013. P. 118)

A considerable number of philosophers, directly influenced from the viewpoint of Kant and Jean-Jacques Rousseau, formulated some concepts that not only overcame the ideas presented from the two above philosophers, but managed to respond to the needs of time, and gave arguments for the phenomenon of reciprocal and established relations between justice and peace. In their formulations, there were ideas according to which justice was evaluated as a human demand and an important virtue that protected the personality of people, through which the rights of man are protected and guaranteed, hence the rights of all human society are guaranteed. 
The essence of these viewpoints is based on the fact of the close relation between the justice of everyone and the peace of all. As Rousseau underlined "Man is the son of nature but fights for his transformation and his own interests." In order to fulfill his needs, he can not live on his own, but only through creating new relations with other beings similar to him. This means that, every achievement man creates for himself, serves also to society, part of which man is.

A necessary element for the realization of peace is the establishment of a justice peace that indicates the permanent presence of natural justice. Martin Luther King particularly emphasized the relation and dependence between peace and justice: "Peace is not created to make justice, but justice is created to make peace." 1

There are some philosophical theories, such as theories of peace, philosophy of peace and war etc., that explain the connection between peace and democracy or capitalism. According to the supporters of peaceful democracy, there is a strong connection between the development of democracy and the contribution that this one gives in the promotion of harmony and peace between nations. According to them, it has its distinctive features and carries peace in itself. Another philosophical thought is the theory of capitalism, which argues that the development of capitalism has helped in the avoidance of conflicts and wars, emphasizing the promotion of peace and harmony.

Nowadays, some philosophers think that there is not just one definition for peace. They think that in modern times, peace is a very wide concept that has to be seen in the pluralist concept and not in a narrow concept of the word. These scholars consider peace not just as a lack of conflict or war, but also as a balance that has to exist between man, nature and universe. They argue that peace cannot be necessarily achieved; it is also something that changes continuously. Such a conclusion is closely related to the challenges of mankind that have to be oriented in such a way in order to avoid wars and resolve conflicts without violence. This is the reason why in our days, peace is treated as a complex and dynamic process.

An important and influential evaluation is presented from the Pacifist Movements, movements that have their origin in the 20-century, period during which they took the deserved place in society. Such movements started during the First World War, but also in the period of protests against war in Vietnam or Iraq. During the period of Cold War between USA and Russian Federation, Pacifists protested against the use of weapons, by thinking that the use of weapons would lead in a new conflict and the explosion of a new world war. The supporters of pacifist movements of our times think that war against terrorism in Iraq, Afghanistan, Syria and elsewhere, cannot be resolved by using weapons, but through other peaceful ways, making space for diplomacy and build a new democratic society through free and fair elections.

Evaluation for problems of peace incarnates the meaning of two sides of a medal. One side of that has to do with the human rights and freedom that man has in society. So, the deepening and the progress of a democratic society, of its form and content, is defined from the fact of how much the individual and the human society "grabs" these rights from state. While the other side of the medal of peace, is conditioned with the establishment of a direct and a stable relation with other nations. However, in any case right and stable peace cannot be realized without justice. It will be established and strengthened when it is based

1 Peace is not created to make justice, but justice is created to make peace - Martin Luther King. 
on legitimate right of people and not based on the interests of some powerful countries, that in the relations between nations and states impose, their hegemony and enslaving politics. This viewpoint, that was represented from individuals who were transformed into symbols of peace and freedom, very soon would become a principal and a working program even for international organizations, that are also guarantees of a permanent and well-established peace. The general front for all now is the permanent education with the feeling of peace between individuals and all human society.

History of humanity witnesses that peace and justice have conquered new spaces according to the level of development of the human society. This is also the reason why addressing concepts on peace, cannot be sufficient without addressing first the reciprocal influence between peace and justice, always in the framework of a defined freedom that witnesses even the level of society itself. This is, because justice and peace are not empty concepts, but values that are won, a common wealth of free and emancipated people. In this sense, the protection and maintenance of peace, requires an all-inclusive commitment of all, considering it as a primary duty of today's society. It's a duty for philosophers to reveal in front of human society, not only the historical and philosophical circumstances and the influence that exists among the freedom of the person himself, the freedom of society, justice and peace, but also the new visions concerning it, as the only alternative on which our human life and the life of universe itself, is built and developed.

\section{United Nations the Guardian of Peace}

Different scholars and philosophers of the last centuries consider the International Organizations as necessary instruments for the protection of peace and prevention of war (Baca 2010 P.16). Although in essence, the International Organizations are structures with economic, political, military, cultural and technic-scientific character that represent different interests according to a common will and ideal, the main duty of them is connected with the avoidance of wars, as a primary practice and method in the process of resolving conflicts between nations and states.

Thus, the Card of the United Nations does not allow the members of UN to interfere in one - another's affair. However, UN, through its peacekeeping missions, and also through surveying missions in states where there is or there was a conflict, has enabled solutions for problems and has established peace. UN also has enabled the avoidance or has given an end to the conflicted situations of those states that can become part of a conflict, putting economic sanctions to the aggressor. UN puts economic sanctions against the government of a state in case of the negotiations in order to solve the conflicts that fail. UN has also created a special court that has the main function as the judgment of war crimes. In July 2002, there was also created a permanent penal court that judges the crimes of war and the genocide exercised against any nation etc.

Only in case of an attack and violation of the independence of a state that is internationally recognized, UN Card gives the right to this organization to interfere in protection of that state. It is the General Secretary, who gathers and commits military forces, in order to interfere and give a rapid solution to the problem. It is a primary duty for peace forces to be neutral, and not to be on the side of one part or not to support one of the states involved in the conflict. 
All the process and the mission of peace keeping is possible and remains under the control of UN Security Council. Peacekeeping operations are under the control of the will of member states of UN, that support it financially, paying the relevant quota and guarantee the needed number of military forces and their logistic support. The mission of $\mathrm{UN}$, as guarantor of peace, can be described as a model that includes different necessities on time and space, incarnating, the time features and the regional features. Obeying the principles of the great founders of UN, the UN has now been transformed into the most important organization in the world, guarantee of world peace and international security. The positive developments of close relations through states in our era are deepening more and more the collaboration among states by providing peace education especially in developing and torn societies. However, the UN plays the role of a world family, protecting the international security and promoting peace education through its institutions all over the world.

\section{Conclusions and Recommendations}

The peoples' desire for peace still remains a distant dream because the mankind inherits the worst problems affecting its own security and self-existence. Thus, the human society still continues to suffer problems such as the consequences of globalization, technological disparity between developed countries having advanced industries and underdeveloped countries still facing political, cultural religious, and territorial conflicts, etc. However, one of the most serious stimulations concerning birth and generation of conflicts is the existence of diversity of thoughts for the world that surrounds us. Such a vital phenomenon gives variety, sense and development to social life, it can be transformed in certain situations in a fierce conflict through two sides, trying to establish the ruling or leading society. What is developed and achieved till today, did not recognize any straight way, but it owes a lot to the presence of contradictions in nature and society, as a law and an objective phenomenon.

Issues related to the peaceful coexistence are not only a property of politicians, national leaders or scholars of social science, but belong to all of us. Every member of the global society has to be aware of his responsibilities. Thus, it is the duty of philosophers and scholars to redeem people from the prejudice deeply rooted in centuries, from dogmas, and from choosing illogical ways and forms, unreasonable and archaic ways of resolving conflicts. The biggest responsibility of scholars is related to the evaluation of human society and its primary role. The way for a peaceful future can naturally come only through cooperation between nations and people, and through respect for their national sovereignty.

\section{References}

Baça, F. (2010). Albania and international organizations. Tirana: Publishing house "Globus R". Dahrendorf, R. (1997). Modern social conflict. Tirana: Publishing house "Dituria".

Dewey, J. (2003). School and society. Tirana: Publishing house "Plejad".

Kant, E. (2004). Perpetual peace. Tirana: Publishing house "Dritan".

Spinoza, B. (2013). Theological and political treaties. Tirana: Publishing house "Pika pa sipërfaqe". 
2018, Vol. 10, No. 3. ISSN 2029-1922

Received 15 November 2018; accepted 22 December 2018

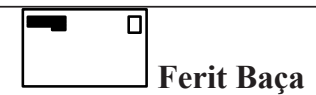

Lecturer, Faculty of Social Sciences, University of Tirana, Tirana, Albania.

E-mail: feritbaca@gmail.com 